\title{
Hva er autonomiens grenser?
}

\section{Valg som tas av personer som er beslutningskompetente skal respekteres av helsepersonell, men det er noen klare grenser.}

\section{Per Nortvedt}

Professor emeritus

Senter for medisinsk etikk, Universitetet i Oslo

\section{Lillian Lillemoen}

forsker

Senter for medisinsk etikk, UiO

\section{Autonomi Etikk \\ Jus Lovverk Pasientrettigheter Psykisk helsevern}

Sykepleien 2016104 (11) (45 46)

DOI: 10.4220/Sykepleiens.2016.59448

$\AA$ A respektere pasientens autonome valg er en sentral normativ føring både i etikk og jus. Idealet om det frie og selvstendige mennesket har som en grunnleggende forutsetning at en person kan ta reflekterte valg, bearbeide relevant informasjon og forstå konsekvensene av mulige handlingsalternativ. Valg som tas av personer som på denne måten er beslutningskompetente, skal respekteres av helsepersonell. Dette gjelder også når disse valg ikke samsvarer med helsepersonells faglige vurderinger og anbefalinger. 


\section{Det finnes grenser}

Det er likevel noen klare grenser for disse føringene, som at en pasient som ikke er beslutningskompetent, ikke uten videre kan trumfe helsepersonellets vurdering om faglig forsvarlighet og hva som er å anse å være til pasientens beste.

Dette innebærer en rett for helsepersonell til under visse vilkår å bruke tvang overfor pasienter som motsetter seg helsehjelp. Disse grensene for autonomi er nedfestet i gjeldende lovverk, for regulering av bruk av tvang i somatiske helsetjenester, lov om pasient- og brukerrettigheter $\$ 4 A$ og når det gjelder psykisk helsehjelp, i psykisk helsevernlov, 3 og $\$ 4$.

En begrensning i autonomi gjelder også pasienters rett til å forlange behandling, som helsepersonell vurderer å ikke være faglig forsvarlig, eller der nytten av behandling ikke står i et rimelig forhold til kostnader.

\section{Særlig etisk kontroversielle}

Det er fire områder for utøvelse av autonomi som er særlig etisk kontroversielle og som også gjelder beslutningskompetente personers rett til å ta beslutninger på egne vegne.

- Det ene gjelder å innføre samme rett til samtykke for pasienter med alvorlig sinnslidelse som for somatiske pasienter. Et forslag, som nå er til behandling i stortinget, er å innføre et kompetansevilkår som begrenser bruk av tvang $\mathrm{i}$ psykisk helsevernlov. Dette innebærer (med visse begrensninger for suicidale pasienter), at pasienter med alvorlig sinnslidelse skal ha en rett til å motsette seg behandling, så fremt de er beslutningskompetente ( Prop. 147 L 2015-2016). Det vil for eksempel innebære en rett for pasienter til å motsette seg medikamentell behandling, selv om dette potensielt kan forverre deres sinnslidelse.

- Det andre området gjelder begrensninger i pasienters rett til å kreve helsehjelp/medisinsk behandling som er vurdert å være for kostbar i 
forhold til den nytte behandlingen gir. Dette er en særdeles utfordrende og omdiskutert del av moderne prioriteringsetikk, som særlig rammer tilgang til dyr livsforlengende behandling med marginal nytte og kort forventet levetid (jamfør eksempler med tilgang til immunterapi i kreftbehandling). For noen år tilbake ønsket en yngre pasient med ALS trakeostomi og respiratorbehandling, - pasienten $\varnothing$ nsket å leve lengst mulig for å kunne være en del av sitt mindreårige barns oppvekst. Helsepersonellets vurdering resulterte i avslag, - man vurderte behandlingens nytte som lav, og at den ville forlenge pasientens lidelse (slik det kom fram i media). Man mente også at pasienten ikke var i stand til å forstå hvilken lidelse hjemmerespiratorbehandling ville innebære. Men her kommer nok et problem - hvordan skal man beregne nytte og hva er kort forventet levetid når man står overfor en reell person, et barn, en familie? Pasienten krevde sin rett til second opinion, - en vurdering som resulterte i at pasienten fikk medhold i sitt ønske om trakeostomi og respiratorbehandling.

- Det tredje området, som har vært omstridt helt fra innføring av Lov om pasient- og brukerrettigheter første gang i 2000, er plikten til å gi øyeblikkelig hjelp når helsehjelpen ansees å være påtrengende nødvendig, slik dette er fastsatt i Helsepersonellovens § 7. Dette er ifølge loven, en plikt for helsepersonell til å gi helsehjelp som også er gjeldende for pasienter som kan samtykke, og som motsetter seg helsehjelp. Begrensninger i denne hjelpeplikten gjelder ved avståelse fra blodtransfusjon, ved sultestreik og hvis pasienten er døende. Men begrensningene gjelder ikke alle pasienter som er samtykkekompetente, og man kan godt tenke seg en pasient som er samtykkekompetent og ikke døende, og som motsetter seg helsehjelp. Å innskrenke retten til å nekte helsehjelp for pasienter som er 
beslutningskompetente er etisk problematisk, selv om helsehjelp er påtrengende nødvendig.

- For det fjerde er det et filosofisk poeng, som understreker problematiske sider ved utøvelsen av autonomi, om enn det ikke på en avgjørende måte begrenser retten til pasientens selvbestemmelse. Vi tenker på de uheldige konsekvenser utøvelse av autonomi noen ganger kan ha for tredje part; for familie, venner, andre pasienter og endog helsepersonell. Smerte, for eksempel, er et fenomen som eksisterer selv om en person aksepterer og lever med sin smerte. En persons smerte kan smerte andre, den viser seg som en moralsk realitet i pasientens kropp, i ansiktsuttrykk og kanskje i manglende motivasjon for tiltak som kan bedre funksjonsnivå. Et annet eksempel, som kanskje ikke er så subtilt, fordi de fleste ønsker nå engang å få lindret sin smerte og ofte er dette mulig: For noen år siden døde en sykehjemsbeboer av liggesår fordi hun motsatte seg stell og pleie i over en måned. Hun fikk til slutt så store liggesår og infeksjoner at hun ble flyttet til kirurgisk avdeling på Akershus universitetssykehus, der hun d $\varnothing$ de. To psykiatere hadde ved tilsyn vurdert at hun var beslutningskompetent, og fylkes- og kommunelegen fastslo at hun derfor ikke kunne påtvinges helsehjelp. Respekt for beboerens autonomi medførte stor belastning på andre beboere og også helsepersonell som måtte se en pasient forkomme, uten å kunne hjelpe. Verdier er således ikke bare noe som hefter ved personers valg og bevisste handlinger, men viser seg også i fenomener som smerte, hjelpeløshet og sårbarhet og har konsekvenser for familie, andre beboere og helsepersonell.

\section{Så stor inngripen}


Mens det i medisinsk etikk er stor aksept for å respektere pasienters rett til samtykke uten begrensninger, så fremt de er beslutningskompetente, gir norsk lov en hjemmel for hjelpeplikt (jamfør Helsepersonellovens $\$ 7$ om $\varnothing y e b l i k k e l i g ~ h j e l p)$. Det var antakelig denne som kom til anvendelse i saken med den kompetente sykehjemsbeboeren som hadde ligget uten pleie i to måneder med begrunnelse i respekt for hennes beslutning.

Men vi må likevel spørre: Vil ikke noen beslutninger innebære en så stor inngripen i pasientens liv at de nærmest blir umulig å gjennomføre, uavhengig av om pasienten er kompetent eller ikke? Og var det riktig, å først akseptere at hun ikke skulle ha pleie og derved forkomme, og så behandle henne når situasjonen ble akutt?

Referanser:

Prop. 147 L (2015-2016). Endringer i psykisk helsevernlov mv. ( $\varnothing k t$ selvbestemmelse og rettsikkerhet). Helse og omsorgsdepartementet.

Lov om helsepersonell (1999). Helse og omsorgsdepartementet.

\section{«Vil ikke noen beslutninger innebære en så stor inngripen i pasientens liv at de nærmest blir umulig å gjennomføre, uavhengig av om pasienten er kompetent eller ikke?»}

